\title{
FLEXIBLE WORKING HOUR ARRANGEMENTS IN BRAZIL
}

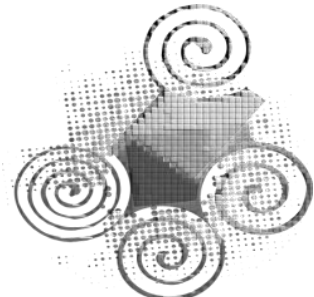

ARRANJOS FLEXÍVEIS DA JORNADA DE TRABALHO NO BRASIL

Recebido em 27.02.2020 Aprovado em 01.06.2020

Avaliado pelo sistema double blind review

DOI: https://doi.org/10.12712/rpca.v14i2.40811

\section{Antonio Carvalho Neto}

carvalhoneto@pucminas.br

Programa de Pós-Graduação em administração/Pontifícia Universidade Católica de Minas Gerais,

Belo Horizonte, Brasil

https://orcid.org/0000-0001-5439-2845

\begin{abstract}
This paper bases on a survey applied to 315 human resources top managers from Brazilian firms regarding flexible working hour arrangements practices. I discuss how flexible arrangements occur in countries with regulatory, voluntarist or hybrid industrial relations systems (Brazil, Europe, USA and Asia). The research shows that flexible arrangements happen mainly as an initiative of managers while collective bargaining between unions and employees hold a third of these initiatives. Half of the arrangements exchanged overtime payment for time-off and $20 \%$ adopted home office and telecommuting; $76.8 \%$ of the companies had greater job satisfaction, productivity and retention of professionals.
\end{abstract}

Keywords: Home Office. Telecommuting. Human Resources Practices. Comparative Industrial Relations Systems.

\section{Resumo}

Este artigo baseia-se em pesquisa aplicada a 315 executivos de empresas operando no Brasil sobre arranjos flexíveis da jornada de trabalho. Discuto como ocorrem arranjos flexíveis em países com sistemas de relações de trabalho regulatórios, voluntaristas ou híbridos (Brasil, Europa, EUA e Ásia). A pesquisa mostra que arranjos flexíveis acontecem principalmente como iniciativa dos gerentes, enquanto a negociação coletiva entre sindicatos e empresas é responsável por um terço dessas iniciativas. Metade dos arranjos trocou pagamento de horas extras por folgas e $20 \%$ adotaram home office e teletrabalho; $76,8 \%$ das empresas apresentaram maior satisfação no trabalho, produtividade e retenção de profissionais.

Palavras-chave: Trabalho no domicílio. Teletrabalho. Práticas de RH. Sistemas de Relações de Trabalho comparados. 


\section{Introduction}

In the context of the broad reconfiguration of contemporary employment relations, flexible work arrangements have been a constant concern for researchers at the international level (Bamber, Ryan \& Wailes, 2004; Richbel, Brookes, Brewster \& Wood, 2011; Peretz, Fried \& Levi, 2018).

This article contributes to the gap in the Brazilian literature in the field of management, considering that several authors (Tenório, 2002; Costa, 2003; Oltramari \& Piccinini, 2006; Lima, Souza, Amorim \& Fisher, 2013) have focused the discussion on the flexibilization of labour relations in general, and the employment contract in particular, but not on the working day. Only one study by Carvalho Neto, Amorim \& Fisher (2016) presented research data from 354 human resource managers in Brazil that were related to the flexibility of the workday; however, not detailing the flexibilization practice and including only two arrangements, namely: working at the home office and working less than a five-day workweek. Moreover, the central research focus of Carvalho Neto et al. (2016) was not the working day per se, which is hereafter the intended focus of this paper. This study presents empirical data on five flexibilization practices relevant to the working day, and is especially timely considering the labour reform that has occurred recently in Brazil.

This work bases on a survey applied to managers at the strategic level of the human resources area of 315 large and medium-sized companies operating in Brazil. The objective of the study was to verify if Brazilian companies were adopting human resource policies and practices in the creation of flexible work arrangements that served the interests of both workers and employers. The human resource managers' perceptions are related to their companies policies and practices regarding to: (i) the adoption of flexible work arrangements; (ii) the differences between arrangements for men and women; (iii) the kinds of arrangements; (iv) the collective bargaining of these arrangements between social actors; (v) the most adopted policies and practices regarding the arrangements in their organizations; (vi) the reasons for the (non) adoption of the arrangements; (vii) the positive and negative returns.

\section{Flexible work arrangements in the world}

The international literature reviewed for this paper presents a variety of practices in effect in several countries regarding the flexibility of the working day, and the interconnections of collective social actors (workers, governments and employers) around the flexibilization theme.

In the Western European developed countries, the traditional standard for Industrial Relations Systems till the end of the 1980s was characterized by the contractual and salaried model, with a long-term employment relationship between employee and employer, full working hours and protections provided by law (Holzmann and Piccinini, 2006).

However, this European model has been changing during the last three decades towards what is called a "flexicurity" model that allows flexibility together with security, some degree of deregulation with some degree of regulation, characterized by: low levels of employment protection; generous unemployment benefits; labor market policies to help the unemployed to regain employment. The flexicurity model suppose a constant negotiation between the collective social actors (Muffels, Crouch \& Wilthagen, 2014; Jensen, 2017). Even inside this framework of changes, so to speak, in some countries there are more social protection as in Denmark, Germany, France and Norway than in others, such as the United Kingdom countries (Marginson \& Galetto, 2016) and Australia (Wilson \& Hadler, 2017).

Nevertheless, several studies stress that even this flexicurity model is in crisis (with different grades of intensity) in the European Union related to an increasing degree of liberal politics oriented to flexible 
labor markets (Muffels, Crouch \& Wilthagen, 2014; Marginson \& Galetto, 2016; Wilson \& Hadler, 2017; Hastings \& Heyes, 2018).

In contrast to the traditional standard of 40 or 44 fixed weekly hours, the adoption of flexible working hours varies according to the legislation of each country and there is no dominant view. However, flexibilization is a reality in various industrial relations systems (Giannikis \& Mihail, 2011; Richbell, Brookes, Brewster \& Wood, 2011), national culture, organizational characteristics and organizational outcomes. A recent study by Peretz, Fried \& Levi (2018) on flexible work arrangements across 21 countries (from Asia, North America, Western and Eastern Europe) points that flexitime, job sharing, compressed workweek and teleworking are being adopted everywhere in the world.

During the last two decades the traditional working day model has being questioned by professionals who today demand more flexible arrangements. Working mothers and fathers, caregivers who need to care for elderly relatives, retirees who still want to stay active while working, and men who partake in housework and childcare represent some of the profiles that seek greater flexibility (Greenberg \& Landry, 2011).

Some flexibilization models aim to accommodate female workers, albeit not only for this reason (Azevedo \& Tonelli, 2014). In Brazil, women's demands for flexible work times were initially investigated by Bruschini (1995) in an analysis of human resources policies in leading companies, highlighting cases of organizations that promoted flexibility in working hours for employees. Some practices were born through collective bargaining with unions. This included, for instance, dismissing workers on Fridays at $2.30 \mathrm{pm}$ while compensating their time lost by adding half an hour onto the other working days. Another study by Andrade and Barbosa (2015) revealed that $98 \%$ of a sample of 694 professional women wanted to have flexibility at work to better align motherhood with their careers.

Seeking to broaden the view on the working day flexibilization some of the main initiatives in Europe, USA and Asia are here discussed. The largest proportion of flexible part-time workers is in the Netherlands (47.8\%), Germany (25.6\%) and in the United Kingdom (25.5\%). They are less prevalent in Bulgaria (2\%), Slovakia (2.9\%) and Greece (5.7\%) (Giannikis \& Mihail, 2011).

Even countries with a high level of state intervention as a regulator within the industrial relations system (IRS), such as Denmark (Jensen, 2017) and Germany, have moved towards more flexible working hours (Bamber, Ryan \& Wailes , 2004). We will consider such IRS regulative as opposed to voluntarist systems, where the state interferes much less in labour relations, as it is the case of the USA and the UK (Carvalho Neto et al., 2016). This article considers as hybrids the IRS oriented towards both regulation and voluntarism.

In Spain, where the IRS is regulatory, there has been a sharp increase of working part-time (4 to 6 hours/day), which was also the result of an economic crisis (Carcedo et al., 2012). In Greece, the IRS is also regulatory and flexibility options for the workday are limited. There is an inadequate social structure in Greece to support those who work and have families as well as a great cultural difficulty concerning men sharing domestic tasks with women (Giannikis \& Mihail, 2011).

In the United Kingdom, a voluntarist system, there is a movement towards flexible time options to benefit the workforce because the challenge the organizations are facing to recruiting and retaining professionals (Budd \& Mumford, 2004; 2013). Since the 1990s, there has been more work from home or at the client site, allowing greater mobility and flexibility for professionals. Workers with young children have the right to request a flexible arrangement and the company can deny it only when proving its unviability (Blyton \& Turnbull, 2004). Currently, approximately three million workers are able to align their work with family demands (Dex \& Sheibil, 2001; Bryan, 2012). 
In the United States, one of the most voluntarist systems in the West, flexible arrangements for the workday have also increased. It faces, nevertheless, the problem of precariousness of work as employers are accustomed to transfer to employees some costs of the market fluctuations such as lack of customers. In a restaurant, for example, when there are no customers, the owner can dismiss the workers without pay for the rest of that day. However, two laws were enacted by the government: the Family and Medical Leave Act (FMLA) which allows employees to take a leave of absence due to illness including illness related to family members, and the Federal Employees Flexible and Compressed Work Schedules Act (FEFCWA) allowing flexible work arrangements for federal employees (Peterson \& Wiens-Tuers, 2014).

Australia also has a voluntarist system, but the flexibilization of the workday is not a subject in question, and a model with long daily working hours prevails. This excessive workload negatively impacts the balance between work and family, generating fatigue and even burnout. However, some isolated work experiences with condensed hours (more than 8 hours per day working less days per week) have generated an increase in total weekly rest hours and have been successful (Brown et al., 2010).

In Hong Kong, the IRS is a hybrid with strict laws but flexible practices. The demand for flexibilization of the working day has grown due to the increase of female participation in the labour market, and the government has made efforts to disseminate flexibilization practices. The Labour Department has organized seminars, supporting the adoption of HR policies and practices, aggregating a network of practitioners in the area, and using the media to propagate successful flexibilization practices (Chou \& Cheung, 2013).

In South Korea, also a hybrid system, the main driver of the flexibilization measures of the workday has been the decline of the female presence in the labor market. In 2005, the presence of women over 15 years of age was $50.5 \%$. In 2012, it decreased to $49.9 \%$, contrary to the growth in most other countries in the world (Lee \& Baek, 2014). The implementation of specific legislation and HR practices related to flexible working hours, home office work, division of labor between two workers, part-time work, day care, maternity leave and family leave are increasing in the country. Motivation and performance were positively impacted by the adoption of these measures (Moon \& Roh, 2010).

Frame 1 summarizes these flexible work arrangements in the countries and regions discussed in this section and more.

Frame 1: Flexible work arrangements in various countries/regions

\begin{tabular}{|c|c|}
\hline $\begin{array}{l}\text { Country/Region and } \\
\text { orientation of the } \\
\text { Industrial Relations } \\
\text { System (IRS) }\end{array}$ & $\begin{array}{l}\text { Actions and issues related to collective social actors } \\
\text { (governments, employers and trade unions representatives) }\end{array}$ \\
\hline $\begin{array}{l}\text { Denmark and Germany } \\
\text { (Regulatory IRS) }\end{array}$ & $\begin{array}{l}\text { Flexibilization of the workday length. } \\
\text { Annualized hours (accumulation of hours during a longer period to use as paid time-off). } \\
\text { Agreements on flexibilization of the workday between employer and employees, with or } \\
\text { without unions. }\end{array}$ \\
\hline $\begin{array}{l}\text { Hungary, Belgium } \\
\text { and Netherlands } \\
\text { (Regulatory IRS) }\end{array}$ & $\begin{array}{l}\text { Bank of hours with annual, semi-annual and bimonthly intervals. } \\
\text { Compressed workweek (more hours of work per day and more days of rest). } \\
\text { Work with unions to favor work-family balance through flexibility } \\
\text { Core values for the implementation of flexibilization initiatives: dialogue, trust and } \\
\text { reciprocity. }\end{array}$ \\
\hline $\begin{array}{l}\text { Spain } \\
\text { (Regulatory IRS) }\end{array}$ & $\begin{array}{l}\text { Adjustments of the regulatory framework are required } \\
\text { Inertia of the companies in the face of the great demand for negotiation. } \\
\text { Lack of willingness of the social actors to advance for legal reasons. } \\
\text { Lack of government capacity to promote negotiations with the various social actors. } \\
\text { Companies tend to lay off workers instead of making work more flexible. }\end{array}$ \\
\hline $\begin{array}{l}\text { Greece } \\
\text { (Regulatory IRS) }\end{array}$ & $\begin{array}{l}\text { The rigidity of the legislation inhibits flexibility initiatives. } \\
\text { Predominance of small and medium enterprises in the economy, where the view that } \\
\text { flexibilization generates an increase in labor costs has a great impact. } \\
\text { The view that flexibility creates loss of control from the HR perspective. }\end{array}$ \\
\hline
\end{tabular}




\begin{tabular}{|c|c|}
\hline & $\begin{array}{l}\text { Inadequate social structure to support those who work and have families; } \\
\text { Cultural difficulty of men sharing domestic tasks with women. }\end{array}$ \\
\hline United Kingdom & $\begin{array}{l}\text { Provision of flexible jobs because organizations face challenges to retain labor. } \\
\text { Since the 1990s, companies have adopted greater mobility of workers and greater flexibility } \\
\text { of the workday; this movement initiated with the banking sector that had a significant } \\
\text { contingent of female employees. } \\
\text { Career breaks allow workers to leave } 2 \text { to } 5 \text { years without pay to attend training courses and } \\
\text { other personal needs, such as looking after friends and family. }\end{array}$ \\
\hline $\begin{array}{l}\text { United States } \\
\text { (Voluntarist IRS) }\end{array}$ & $\begin{array}{l}\text { Since the } 1970 \text { s, flexibility strategies have been adopted. } \\
\text { It is the most voluntarist developed country; employers have ample freedom to negotiate } \\
\text { individual contracts with workers; there are less worker rights compared to other countries } \\
\text { discussed; fewer labor protection laws } \\
\text { Flexibilization is related to the precariousness of work. } \\
\text { Government actions amending legislation include the FMLA to allow leave of absence in } \\
\text { case of personal illness or illness in the family. The FEFCWA to allow flexible work } \\
\text { arrangements for federal employees in The USA. }\end{array}$ \\
\hline $\begin{array}{l}\text { Australia } \\
\text { (Voluntarist IRS) }\end{array}$ & $\begin{array}{l}\text { Prevalence for long work hours ( } 10 \text { hours per weekday plus } 5 \text { hours on Saturday). } \\
\text { Difficult balance between work and family, high burnout rates. } \\
\text { Successful isolated experiments with condensed week regimes. }\end{array}$ \\
\hline $\begin{array}{l}\text { Hong Kong } \\
\text { (Hybrid IRS: strict } \\
\text { legislation and flexible } \\
\text { practices) }\end{array}$ & $\begin{array}{l}\text { Demand for flexibilization of the day has grown, especially due to the increase of female } \\
\text { participation in the labor market. } \\
\text { Government has induced companies to adopt five working days a week. } \\
\text { The government has been organizing seminars supporting the adoption of successful } \\
\text { flexibilization practices and disseminating them in the media. }\end{array}$ \\
\hline $\begin{array}{l}\text { South Korea } \\
\text { (Hybrid IRS) }\end{array}$ & $\begin{array}{l}\text { The reduction of women in the labor market and the decrease in the birth rate have led to } \\
\text { more flexibilization of the working hours and place, as well as the division of labor, part- } \\
\text { time work, construction of day care centers, maternity leave and time to handle family } \\
\text { matters. }\end{array}$ \\
\hline
\end{tabular}

Sources: elaborated by the author based on: Dex \& Sheibil, 2001; Bamber, Ryan \&Wailes, 2004; Budd \& Mumford, 2004; Atkinson \& Hall, 2009; Brown et al., 2010; Moon \& Roh, 2010; Giannikis \& Mihail, 2011; Bryan, 2012; Carcedo et al., 2012; Chou \& Cheung, 2013; Teasdale, 2013; Lee \& Baek, 2014; Muffels, Crouch \& Wilthagen, 2014; Peterson \& Wiens-Tuers, 2014; Carvalho Neto et al., 2016; Marginson \& Galetto, 2016; Wilson \& Hadler, 2017; Zartaloudis \& Kornelakis. 2017; Jensen, 2017; Hastings \& Heyes, 2018; Peretz, Fried \& Levi, 2018).

\section{Flexible work arrangements in Brazil}

Since the end of 2017, Brazil has been experiencing the effects of a labour reform that produced the greatest degree of flexibility in legislation in 70 years, in addition to reducing the power of trade unions and limiting the action of the Labour Courts. Labour reform enables a direct agreement between company and employee to reduce wages as well as some rights and benefits, in addition to facilitating dismissal and changes in the contract and working hours, all without the protection of the union (Krein, 2018).

The main changes brought by the labour reform in relation to the working hours were:

- the daily working hours may be 12 hours followed by 36 hours off, respecting the limit of 44 hours per week and 220 hours per month (Costa, Costa, Rodrigues \& Claro, 2020);

- activities such as meal times, personal hygiene, changing uniforms and studying within the firm are no longer considered part of the daily workday (Costa et al., 2020);

- the overtime accumulated during a certain period of time can be negotiated by individual agreement employee-employer and it is no longer necessary to be negotiated by the employer and the union (Costa et al., 2020); 
- the time the worker spends commuting from home to the workplace, even with transportation provided by the employer, is no longer mandatory to be paid to the employee (Costa et al., 2020);

- home office: regulated by the labour reform; everything the worker uses at home will be formalized with the employer via contract, such as equipment, energy and internet expenses; work control will be done by task (Costa et al., 2020; Haubrich \& Froehlich, 2020).

Due to this new labour legislation, employers do not need to negotiate work arrangements with unions. Employers can impose them unilaterally.

However, the home office in Brazil is still not widespread two years after the labour reform was launched (Haubrich \& Froehlich, 2020), which is explained by some time needed for the labour relations system to adapt to such profound changes. Certainly, with the extraordinary boost in the home office practice that the coronavirus pandemic caused, this situation tends to change very quickly from now on.

Even so, Brazilian public service has used home office (Filardi, Castro \& Zanini, 2020) and the benefits are the same as in private companies (Haubrich \& Froehlich, 2020). This is in line with the international experiences discussed in this article in the previous section, namely: greater productivity; possibility of hiring professionals who live in any geographic location; reduction of the employer's expenses with the structure; improvement in the workers quality of life; and eliminating commuting time from home to the workplace.

\section{The Pros and Cons for Collective Social Actors}

The possibility of reconciling work with the care of family members, especially children care, is a strong motivator for many workers to seek for flexible arrangements (Shockley \& Allen, 2012). Employees in flexible arrangements choose non-standard hours or work in alternative locations and can be more efficient and productive. Home office, for example, can allow the individual to be silent without interruption and this could make the worker focus more, innovate or create. Some studies show a positive correlation between productivity and flexible working arrangements (Gajendran \& Harrison, 2007). Studies also show that there is a decrease in absenteeism, increased productivity and job satisfaction when considering flexible work arrangements (Greenberg Landry, 2011).

Gender, marital status and caring for children are issues correlated to the flexible arrangements of the working day. Employees with partners and children experience more conflicts between work and other spheres of life. Flexible arrangements allow this competition between roles to be more balanced (Ashford \& Kreiner, 2000; Shockley \& Allen, 2012). Studies show that women returning to work in flexible arrangements, after the birth of their first child, deal better with fatigue and stress, as well as demonstrate increased loyalty to the organization (Schwartz, 1989; Greenberg \& Landry, 2011).

The literature discusses also negative points about the flexibilization of the working day. As far as issues related to women, some authors argue that flexible arrangements reinforce the devaluation of the presence of women top executives in organizations, since women partake in most of these flexible arrangements (Peretz, Fried \& Levi, 2018). There is also a negative perception in terms of career development when a professional chooses flexible formats. Research shows that women in this situation receive a label of "mother and professional", and this poses a challenge for their further professional development, better pay and promotions. There is a general perception of less commitment of the professional working in flexible arrangements (McDonald et al., 2007).

Labour legislation is a premise and a fundamental factor in negotiating and debating the flexible arrangements of the working day. Every country has a different legislation, and the monitoring of such legislation is crucial in determining what progress can be achieved in terms of flexibility. Safeguarding 
traditional models and encouraging full-time work are important issues at stake when advancing the flexibility of working hours. According to Giannikis \& Mihail (2011) flexible arrangements should be implemented through agreement between parts, and should take into account the workers' choices as well as gender, marital status and the presence of children to avoid reinforcement of stereotypes and discrimination.

Another point that hinders flexible arrangements is that it requires complex bargaining processes that may be either individually or collectively achieved by trade unions. Considering collective bargaining, studies reveal that if the organization's culture does not support the balance between personal and professional life, the implementation of flexible arrangements remains only in the discourse (Greenberg \& Landry, 2011).

The action of unions, in the case of Brazil, is important because these collective social actors can fill a gap related to aspects not contemplated in the labor legislation through collective bargaining (Vignoli, 2010). However, this is a great challenge, since there are more than 10,000 unions in Brazil (Cardoso, 2013), but no representation in many geographic regions and economic segments. In addition, the necessary dialogue between the HR area and the labor unions in Brazil is rather incipient (Carvalho Neto et al., 2016). Since the labour reform that took place in 2017 , this situation has worsened, as collective bargaining has lost strength as the power of union representation has weakened.

The flexibilization of the working hours implies the predominance of a protection for workers in a negotiated rather than imposed form. The most reasonable way of implementing flexible arrangements is through collective bargaining in order to allow the continuity of employment and the survival of organizations in times of crisis (Vignoli, 2010). The workers ' will must be considered during these negotiations, which does not seem to be happening in the Brazilian context.

\section{Methodology}

The objective of this research is to verify if and to what extent Brazilian companies are adopting HR policies and practices in the creation of flexible work arrangements that serve the interests of both workers and employers. It investigated the perception of HR managers in relation to: (a) the adoption of flexible arrangements in companies (b) the differences between these arrangements for men and women; (c) the types of work agreements or contracts and flexibilization policies; (d) the social actors participating in the collective negotiations of the arrangements; (e) the most adopted policies and practices regarding flexibilization in organizations; (f) the reasons for the (non) adoption of the arrangements; (g) the positive and negative returns of flexibilization.

A descriptive quantitative study (Churchill, 1987) was carried out in 2016 using a survey that was applied to 315 managers at the strategic level of the HR areas of large and medium-sized companies in Brazil. In the survey conducted, a link was sent by e-mail for the sample population to respond. The sample used was non-probabilistic due to accessibility and was based on the definition, a priori, of the selection criteria by position and area of activity of the HR representative of each of the 315 companies. The focus was on the managerial group (supervisors, coordinators, managers, directors and vice-presidents) of the HR area of organizations.

The data collection instrument was a questionnaire (see appendix 1). It uses closed questions in the following forms: dichotomous (with two possible answers), multiple choice (with one or more possible answers), Likert scale of five (to assess the degree of agreement or disagreement of HR professionals on the subject) and scale of importance (to evaluate certain attributes related to flexibilization). 
Pretesting of the questionnaire was conducted with professionals within the profile of the sample, and adjustments were made to the instrument. After the pretesting the link was sent by e-mail to 6,500 professionals from the database of an organization that has been involved with the development of entrepreneurs and executives for more than four decades. Every year, about 50,000 professionals from management positions (including various age groups and from large and medium-sized companies operating in Brazil) participate in the leadership and management development programs of this organization. This database was available to the authors of this paper, and the return obtained was 370 questionnaires from different companies; 315 were validated.

The chi-square test was used to analyze the data of the survey, which allowed evaluation of the relation between two categorical variables, in which at least one was not ordinal. This is done by comparing the observed values in each category with the expected or estimated values (Soares \& Siqueira, 2002; Motta \& Oliveira Filho, 2009). The test was used in most of the cross-checking performed in this study to evaluate the statistical significance between the variables. As an example, to analyze the size of the company in relation to whether or not it adopts policies and practices to make the working day more flexible. Statistically significant associations between the variables were identified from these tests when the p-value was lower than 0.05 .

\section{Findings and discussion}

Out of the 315 companies surveyed, 40\% had more than 2,000 employees. Their activities spanned the most diverse economic sectors: chemical and petrochemical $(7.3 \%)$, steel and mining $(6 \%)$, technology and computing (5.4\%) and public services (5.1\%). The activity of companies concentrated in the Southeastern region of Brazil was the highest at $25.7 \%$, and $21.9 \%$ of the companies were active throughout the whole country while $21.3 \%$ were multinationals. The following chart shows the breakdown of companies by geographic region.

\section{Chart 1: Geographic distribution of company activities}

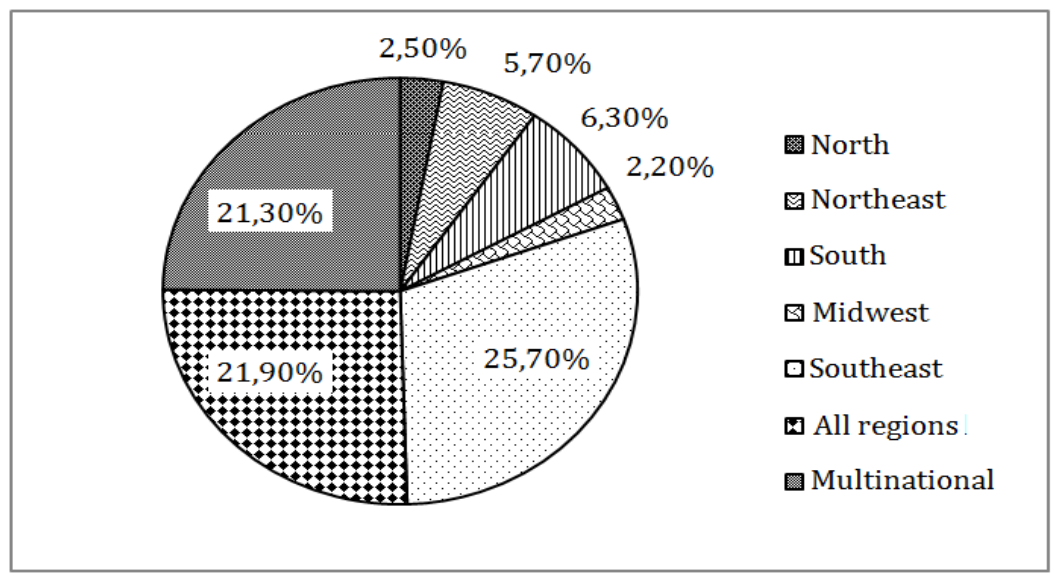

Source: Data from the research.

In $52.6 \%$ of the sample, there is total and partial agreement that companies adopt flexible arrangements for the workday. There is total and partial disagreement in $45.6 \%$. A positive correlation was identified between the adoption of flexible arrangements and company size $(p=0.000)$ as well as with the market segment $(p=0.608)$. Large companies and more traditional and regulated segments tend to be less flexible especially because they are regulated by state agents (from federal government regional 
departments such as the Labour Department - Delegacias Regionais do Trabalho - and by prosecutors of the Justice system - Ministério Público do Trabalho).

It can be verified, by an open-ended question in the survey, that corporate respondents are generally apprehensive about liabilities related to labour issues with the Justiça do Trabalho (part of the judiciary branch that handles labour litigation) when less traditional models are abandoned and flexible working day arrangements are implemented. On the other hand, medium-sized companies tend to be less monitored, more informal and adopt greater flexibility in workday arrangements. There are complaints about the lack of government professionals to operationalize the inspections; therefore, the focus is usually on large companies to gain more visibility (Antunes \& Alves, 2004; Amorim, 2015).

Flexible arrangements considering men and women were also considered and the data revealed that there is no difference. For $58.4 \%$ of the interviewees there were flexible arrangements for both men and women alike, while at $40.9 \%$ of companies there were no flexible arrangements for either men or women. Only $0.6 \%$ of the HR managers interviewed said that their companies adopted flexible arrangements only for women. The data reveal that in the implementation of flexible arrangements there is no bias towards issues of career compatibility with maternity, for example.

Two currents can be perceived. In the first current, the research reveals that the female career is conducive to the implementation of flexible arrangements, since the challenge of reconciling child care with work falls far more on women in various societies (Atkinson \& Hall, 2009; Moon \& Roh, 2010, Chou \& Cheung, 2013, Lee \& Baek, 2014). In another current, researchers argue that defining flexibilization policies and practices for women alone can increase discrimination against the female presence at the workplace.

Even though the massive entry of women into the labour market in most countries has diminished the trend, discrimination is still especially apparent in the spectrum of top positions in organizations (Allen et al., 2013, McCrate, 2012, McDonald, Pini \& Bradley, 2007). The role played by people, regardless of gender, is shared also in the private sphere, within the family. The flexible arrangement of the working day can certainly help professionals dealing with the challenging task of reconciling work and family life, especially caring for children, the sick and the elderly (Haar, 2013).

The importance of collective social actors (government, workers' unions and employers) and their agents (HR departments, corporate legal departments, trade union leaders) in relation to negotiating flexible arrangements in organizations was evaluated from the perspective of the HR managers of the 315 companies. The following results were rated in order of importance: HR managers ( $58.7 \%$ of the sample), the legal department of the company (41.3\%), the workers' unions $(33.3 \%)$, the workers' immediate leadership (29.8\%) and the individual employee (27.3\%). Chart 2 shows this distribution.

The HR area points to itself as the most important for obvious reasons, since any practice of flexibilizing the workday has to go through the HR departments when it comes to implementation and monitoring, for example. The importance of the legal department is highlighted in second place for similar reasons; in a country where the labour relations system is regulatory in nature, organizations need to turn to their lawyers frequently to have some legal certainty that changes in work schedules will not lead to litigation.

It is worth noting that the importance of the negotiation by the employees' immediate leadership is rated almost at the same level as the individual negotiation done by the employee. This suggests that direct management only addresses the issue when triggered by the employee's concern.

The data also show that the employee voice has been relegated during the bargaining process. There is obviously an institutional path to the discussion, but there is a void when it comes to listening to the individual voices that, when paired with the organizational collective, can change the paths hitherto pursued at the negotiating level. 


\section{Chart 2: Actors and agents involved in negotiations regarding flexible working day arrangements}

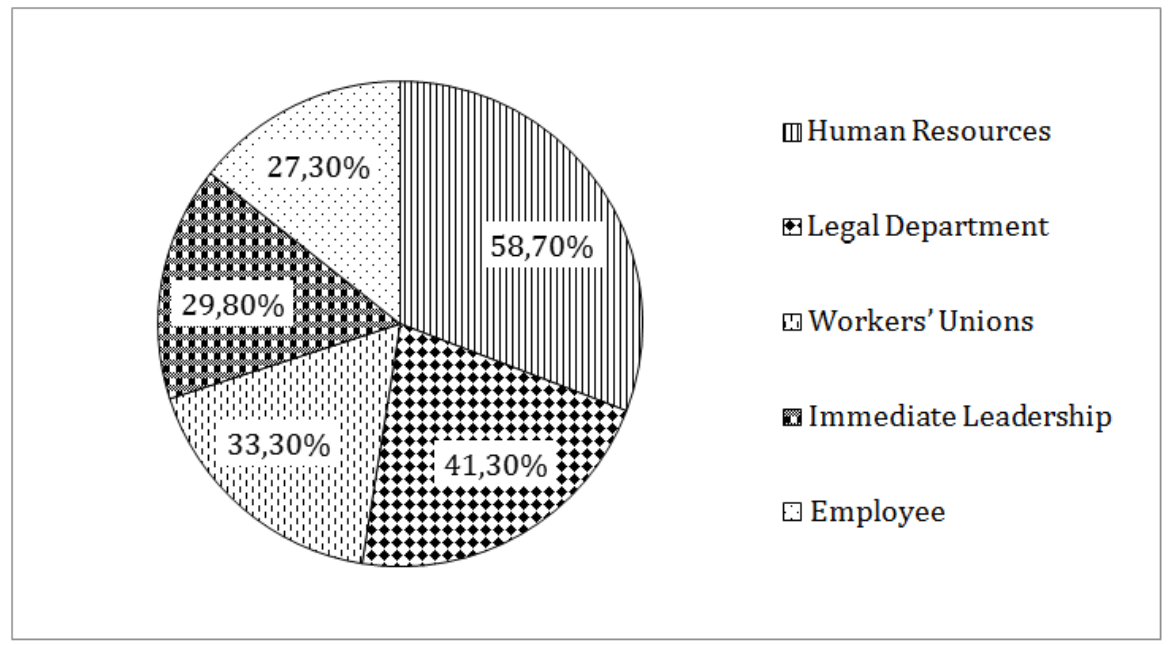

Source: Data from the research.

The participation of labour unions is viewed by $33.3 \%$ of HR managers interviewed as the third most influential in the negotiation of flexible working arrangements, only behind the HR area and the legal department of the organizations, but more influential than the workers' immediate leadership (29.80\%) and the individual worker himself $(27.3 \%)$. For the interviewees, the union participates only once a year $(36.6 \%)$. This is consistent with the fact that, traditionally in labour relations in Brazil, the union negotiates with the company once a year when salaries and benefits are increased (or not) for each professional category.

With rare exceptions, the Brazilian unions have little tradition of systematically monitoring compliance with collective agreements. Private companies are required by law to promote collective bargaining, but not to reach an agreement.

In Brazil, what prevails is a mixed model of centralized collective agreements involving dozens, sometimes hundreds, of companies and unions associated with decentralized collective agreements between a company and a union. There is a tendency for very few concessions on behalf of the companies in the collective agreements, considering that there is significant heterogeneity in the profile of the organizations that take part in the centralized collective bargaining. The most active trade unions carry out a decentralized complementary negotiation to achieve specific advantages per company. Collective agreements with large corporations present far more concessions than are permitted by legislation and innovate in interesting issues such as the extension of parental leave, for example (Antunes \& Alves, 2004; Amorim, 2015).

A positive correlation was identified between the adoption of flexible working arrangements and the participation of the workers' unions $(p=0.000)$, reinforcing the importance of the involvement of this social actor. The importance of unions for workers is clear, although there is no active trade union presence in all market segments. In order to comply with legislation and promote the implementation of flexible arrangements in an effective and mature manner in Brazil, the involvement of this actor is imperative. Examples of countries that have adopted flexibilization more successfully, such as Denmark, Germany, Hungary, Belgium and the Netherlands emphasize the importance of trade union dialogue, reinforcing the role of the decentralization of collective bargaining (i.e., the union negotiates per company, facilitating more creative agreements and adapting to the different realities and organizational contexts) (Ilsoe, 2010). The most practiced kinds of flexible arrangements adopted by large and mediumsized Brazilian companies in this study were: 
- Bank of hours for $58.7 \%$ of the companies: Brazilian legislation allows the accumulation of a certain number of overtime hours in a bank of hours, during a certain lack of time, compensated in cash or time-off. This must be negotiated and agreed between trade unions and companies;

- Exchange of overtime payment for time-off for 39.7\% of the companies: Brazilian law allows more than the legal percentage of $50 \%$ over the extra hourly wage for each extra hour performed. The exchange for time-off can be negotiated between unions and companies;

- Workdays that do not exceed contracted time for 30.5\% of companies: this is not really a flexibilization practice, but was considered important by the HR managers interviewed since the general trend has been the requirement of long working days;

- Home-office adoption for $22.5 \%$ of companies: Working at home is already a reality for a surprisingly significant number of organizations, considering the potential labor problems that this practice can bring before the rigid Brazilian labor legislation and apprehensiveness of companies in regards to regulation;

- Flexibility of the workplace for $18.7 \%$ of companies: The difference in relation to working from home is the possibility of working in places other than the company, such as remote work from virtual platforms or in physical offices rented by time such as shared office spaces.

The most practiced policies and practices found in the study are in Chart 3. The research shows that the most contemporary practices are being adopted, although the most practiced ones are still the traditional ones, which only partially meet the flexibility demands of present-day professionals.

\section{Chart 3: Most common flexible work arrangement practices in Brazil}

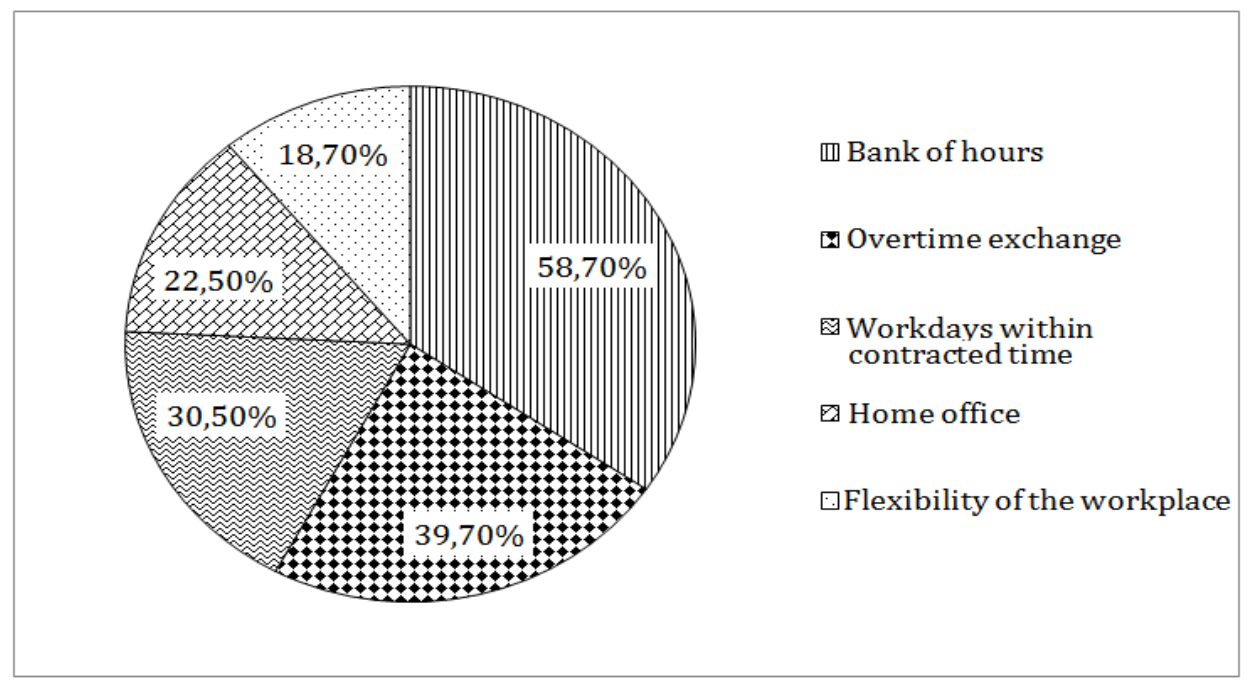

Source: Research data.

A correlation analysis was performed and it was determined that there was no positive correlation between the adoption of flexible hours and the size of the company. It appears that adopted policies are independent of the size of the organization to accommodate some of the professionals demanding flexibility.

The HR area and all managers have the responsibility of finding alternatives to retain professionals that generate competitive advantage for the organization. Without adopting flexible policies and practices, the company potentially loses valuable professionals, as is the case with many professional women who are mothers of young children. When they opt for maternity, they find it difficult to reconcile fixed and strict work schedules with family demands. Because of that, they resign to work for organizations that offer flexible schedules that allow them a better work-life balance. In this aspect, the research confirms that the HR area is not conducting negotiations between companies and unions, and most common practices do not serve these women in particular. 
The main negative returns for the companies were analysed also. The responses of managers and HR show a strong prejudice regarding flexible arrangements, corroborating the extant literature (Shockley \& Allen, 2012). For 30.5\% there is marginalization of professionals who choose flexible arrangements, and $25.1 \%$ believe that there is a perception of low commitment of these professionals. There is still a kind of deification of the workaholic in the organizations (Tanure, Carvalho Neto \& Andrade, 2009).

To challenge this view, it is necessary to look at the level of the organizational culture with the intent of not harming the professional that chooses a flexible work schedule. Denying a promotion or choosing to work a reduced number of hours, for example, can sound like lack of commitment to the organization. Adopting flexible practices could contribute to breaking down prejudices and paradigms on the one hand. The view that a professional reflects lack of commitment if he/she seeks flexibility for a better work-life balance with more autonomy to serve the company and other spheres of life (such as caring for their children) should be contested. Furthermore, in a time of economic crisis, the adoption of flexible working arrangements can be an action that reduces costs.

However, the breakdown of negative perceptions regarding the adoption of flexible arrangements is a cultural change that takes time to develop (Greenberg \& Landry, 2011). If the organizational culture does not value the balance between personal and professional life, most likely the genuine adoption of the flexible work arrangements, which is not only focused on reducing labour costs, but also on giving autonomy, generating satisfaction and positively impacting productivity of workers, will not find space at the negotiation table.

Considering main positive returns, both from the point of view of the employee and the employer, with the intention of advancing the debate and bringing flexible work arrangements to the negotiation table, $76.8 \%$ of the 315 companies had greater job satisfaction when considering the adoption of flexible arrangements. For $56.5 \%$ of HR managers interviewed, productivity was the main positive return. For $47.9 \%$, flexibilization of the day allowed the capture and retention of professionals who would not otherwise have come or continued to work in the company.

Only $2.5 \%$ of HR managers did not see a positive return in adopting flexible arrangements. This data reveals that there is room to articulate a more consistent debate about the adoption of flexible arrangements in Brazilian organizations. Linking flexibilization with precariousness is understandable, unfortunately. But here I refer to a different kind of flexibilization, the one that interests to a segment of high skilled workers. We are talking about HR practices adopted in advanced countries with regulatory systems such as Denmark, Germany and Belgium.

In order to advance employment relations in Brazil, the negotiations of flexible work arrangements cannot be limiting and prevent dialogues between agents and collective social actors. The context of the current Brazilian labour market calls for a conversation among professionals, companies representatives, union leaders and other social actors who want work, but also want quality of life and dignity above all else.

\section{Final Considerations}

This paper intends to contribute to the limited view that directly associates the flexibilization of the working day with the precarization of work. It reflects upon potential paths for negotiations that take into account flexible arrangements. Other countries, with industrial relations systems that are regulatory in nature like the Brazilian system, have succeeded through mature negotiations among the collective social actors. This has enabled the implementation of flexible arrangements and has addressed the interests of workers and employers alike. 
The research that supported this study revealed more agreements than disagreements, among the 315 companies studied, that flexible arrangements are being implemented in the Brazilian organizational context. Large companies and more traditional segments tend to be less flexible and fear to innovate in terms of working day flexibility, fearing possible accumulation of labor liabilities. The rigidity of legislation, coupled with greater oversight directed at large companies, provokes a somewhat exaggerated fear, which inhibits the implementation of more flexible working hours. On the other hand, mediumsized companies, which are less monitored, have a tendency to adopt more flexible practices.

Among the HR practices of flexible arrangements, it is worth noting the significant presence of the home office and the flexibility of workplace practices, considering that at least about one fifth of the companies have conquered their professed fear of labor liabilities while adopting these practices. These are concrete practices that can generate greater satisfaction, productivity and contribute to attract and retain qualified professionals for the organization. The non-correlation between the size of the organization and the flexibility of hours indicates that this strategy could be disseminated in all organizations.

There is no data on the individual desire of employees regarding the implementation of flexible arrangements in this research, which remains as a suggestion for future research. Listening to the employee is important to move forward with these practices. Women, as mentioned in the literature, were one of the instigators of the adoption of flexible models of the working day. They are benefitted on one hand by being able to reconcile better the roles of being a mother and a professional, for example.

On the other hand, by adopting the flexibility of the workday, women can be hampered by the prejudice that affects the worker who opts for the flexible model which is often perceived as lack of commitment as discussed in the study. From the organizational perspective, it might be more effective not to associate gender with flexible arrangements of the working day. The literature indicates that both professionals that have and those that do not have children see concrete benefits in making the working day more flexible. Disentangling gender from flexible working hours can help minimize stereotypes.

The path to enable the implementation of flexible arrangements of the working day passes through the HR area, naturally. This area should be the great mediator of the interests and desires of the employer and the worker. However, this intermediation may not materialize in Brazil. The study showed that in almost half of the companies the HR area is not involved in this issue. Another important agent is the legal department of organizations, which has the function of providing legal certainty to enable or not the implementation of flexible arrangements in the working day.

Lastly, the union is another collective social actor pointed out by corporate HR managers as a key player in the process of implementing flexible arrangements, and can play the role of contributing or boycotting initiatives. The collective bargaining promoted by the unions could be the fundamental instrument that fills the gap of a new legislation. It could establish guarantees for the workers on one side, and on the other, it would embrace the distinct reality of a country with the continental dimensions of Brazil.

In order to advance the creation of flexible work arrangements that serve the interests of both workers and employers in Brazil, there is a need for a more mature position in a tripartite negotiation between government, workers and employers. However, it is a scenario hard to imagine in a country marked by deep mistrust among these three collective social actors, especially after the weakening of the bargaining power of the unions caused by labour reform.

From the exclusive point of view of employers, as labour reform has made many laws regarding working hours more flexible, there is a possibility that flexible work arrangements will be used much more unilaterally in the near future by organizations. 
Adding to this picture, the huge increase in home office in all sectors of the economy caused by the coronavirus pandemic point out a trend from now on for organizations to take advantage of the perceived gains and maintain a much larger proportion of home office, which is why this work is important.

\section{References}

Allen, T.; Johnson, R. C.; Kiburtz, K.M. \& Schockley, K.M. (2013). Work-Family Conflict and Flexible Work Arrangements: Deconstructing Flexibility. Personnel Psychology, 66, 345-376.

Amorim, W. (2015). Negociações Coletivas no Brasil: 50 Anos de Aprendizado. S.P.: Atlas.

Andrade, J. O. \& Barbosa, A.C.Q. (2015). Instrumentos, Políticas e Práticas de Recursos Humanos para as Mulheres Profissionais: Propostas para Inspirar as Organizações. In: Andrade, J. O \& Carvalho Neto. Mulheres Profissionais e Suas Carreiras Sem Censura: Estudos sob Diferentes Abordagens. São Paulo: Atlas.

Antunes, R. \& Alves, G. (2004). As Mutações no Mundo do Trabalho na Era da Mundialização do Capital. Educ. Soc. Campinas, v.25, n.87, p.335-351.

Ashforth, B.E.; Kreiner, G.E. \& Fulgate, M. (2000). All in a day work: Boundaries and micro role transitions. Academy of Management Review, 25, 472-491.

Atkinson, C. \& Hall, L. (2009). The Role of Gender in Varying Forms of Flexible Working. Gender, Work and Organization, V.16, n.6.

Azevedo, M.C. \& Tonelli, M.J. (2014). Os diferentes contratos de trabalho entre trabalhadores qualificados brasileiros. RAM - Revista de Administração Mackenz̧ie, 15(3). Edição Especial. p. 191-220.

Bamber, G. J., Ryan, S. \& Wailes, N. (2004). Globalization, employment relations and human resources indicators in ten developed market economies: international data sets. The International Journal of Human Resource Management, 15(8), 1481-1516.

Blyton, P.; Turnbull, P. (2004). The dynamics of employee relations. Palgrave Macmillan.

Brown, K.; Bradley, L.; Lingard, H. Townsend, K. \& Ling, S. (2010). Working Time Arrangements and Recreation: Making Time for Weekends when Working Long Hours. Australian Bulletin of Labour. v. 36, n.2.

Bryan, M.L. (2012). Access to Flexible Working and Informal Care. Scottish Journal of Political Economy, v.59, n.4.

Bruschini, C. (1995). Mulher e Trabalho: Políticas de Recursos Humanos em Empresas de Ponta. São Paulo: Fundação Carlos Chagas - Cadernos de Pesquisa, n.95, p.13-24.

Budd, J.W. \& Mumford, K. (2004). Trade Unions and Family Friendly Policies in Britain. Industrial and Labour Relations Review, v.57, n.2.

Carcedo, J.M.; Campos, F.G.B. \& Carrasco, V.B.A. (2012). Flexibilidad del tiempo de trabajo em España: ¿Ha alterado la crisis el comportamiento del empleo a tiempo parcial? Estudios de Economia Aplicada. v.30, n. 1., p.209-236.

Cardoso, A. (2014). Os Sindicatos no Brasil. Nota Técnica IPEA: Mercado de Trabalho. v.56.

Carvalho Neto, A., Amorim, W., \& Fischer, A. (2016). Top Human Resources Managers Views on Trade Union Action in Brazilian Corporations. Brazilian Administration Review, 13(4), 1-23. 
Chou, K.L. \& Cheung, K.C.K (2013). Family-friendly policies in the workplace and their effect on worklife conflicts in Hong Kong. The International Journal of Human Resource Management, v.24, n.20, p. 38723885.

Churchill Jr., G. A. (1987). Marketing research: methodological foundations. Chicago: The Dryden Press.

Costa, B. C., Costa, M. C., Rodrigues, M. \& Claro, S. R. da S. (2020). CLT - LTr. São Paulo: LTr.

Costa, M. S. (2003). Reestruturação Produtiva, Sindicatos e a Flexibilização das Relações de Trabalho no Brasil. RAE, v.2, n.2.

Dex, S. \& Schebil, F. (2001). Flexible and Family-Friendly Working Arrangements in UK-Based SMEs: Business Cases. British Journal of Industrial Relations. v.39, n.3.

Filardi, F., Castro, R. M., \& Zanini, M. T. F. (2020). Vantagens e Desvantagens do Teletrabalho na Administração Pública: Análise das Experiências do Serpro e da Receita Federal. Cadernos EBAPE.BR, 18(1), 28-46.

Gajendran, R. S. \& Harrison, D. A. (2007). The good, the bad, and the unknown about telecommuting: Meta-analysis of psychological mediators and individual consequences. Journal of Applied Psychology, V. 92, p. 1524-1541.

Giannikis, S. K., \& Mihail, D. M. Flexible work arrangements in Greece: a study of employee perceptions. (2011) The International Journal of Human Resource Management, 22(2), 417-432.

Greenberg, D. \& Landry, E. M. (2011). Negotiating a flexible work arrangement: How women navigate the influence of power and organizational context. Journal of Organizational Behaviour.v.32, p. 1163-1188.

Haar, J. M. (2013). Testing a new measure of work-life balance: a study of parent and non-parent employees from New Zealand. International Journal of Human Resource Management. v.24, n. 17, p. 3305-3324.

Hastings, T., \& Heyes, J. (2018). Farewell to flexicurity? Austerity and labour policies in the European Union. Economic and Industrial Democracy, 39(3), 458-480. https://doi.org/10.1177/0143831X16633756

Haubrich, D. B., \& Froehlich, C. (2020). Benefícios e Desafios do 'Home Office' em Empresas de Tecnologia da Informação. Gestão \& Conexões, 9(1), 167-184.).

Ilsoe, A. (2010). Between trust and control: company-level bargaining on flexible working hours in Danish and German metal industries. Industrial Relations Journal, 41: 1, 34-51.

Jensen, P. H. (2017). Danish flexicurity: preconditions and future prospects, (2016), 218-230. https://doi.org/10.1111/irj.12176

Krein, J. D. (2018). O desmonte dos direitos, as novas configurações do trabalho e o esvaziamento da ação coletiva: consequências da reforma trabalhista. Tempo social, 30(1), 77-104.

Lee, S.S. \& Baek S. (2014). Why the Social Investment Aproach is not Enough - The Female Labour Market and Family Policy in the Republic of Korea. Social, Politics and Administration. v.48, n.6; p. 686-703.

Lima, L.; Souza, T.S.; Amorim, W. \& Fisher, A. (2013). Apropriações da Flexibilização das Relações de Trabalho pela Administração de RH: Estudo Comparativo entre as Produções Acadêmicas Nacionais e Internacionais. Revista Gestão \& Tecnologia. v.13, n.3, p.151-177.

Marginson, P., \& Galetto, M. (2016). Engaging with flexibility and security: Rediscovering the role of collective bargaining. Economic and Industrial Democracy, 37(1), 95-117. https://doi.org/10.1177/0143831X14538850 
McCrate, E. (2012). Flexibility for Whom? Control Over Work Schedule Variability in the US. Feminist Economics. ed.18, n 1, 39-72.

McDonald, P.; Pini, B. \& Bradley, L. (2007). Freedom or fallout in local government? How work-life culture impacts employees using flexible work practices. International Journal of Human Resource Management. 18:4, 602-622.

Moon, S. \& Roh, J. (2010). Balancing Work and Family in South Korea's Public Organizations: Focusing on Family-Friendly Policies in Elementary School Organizations. Public Personnel Management. v. 39, n.2.

Motta, V.T. \& Oliveira Filho, P.F. (2009). SPSS Análise de Dados Biomédicos. RJ: Medbook.

Muffels, R., Crouch, C., \& Wilthagen, T. (2014). Flexibility and security: National social models in transitional labour markets. Transfer: European Review of Labour and Research, 20(1), 99-114. https://doi.org/10.1177/1024258913514361

Oltramari, A.P. \& Piccinini, V.C. (2006). Reestruturação Produtiva e Formas de Flexibilização do Trabalho. Revista Organizaçãa \& Sociedade.v.13, n.36.

Peretz H, Fried Y, Levi A. (2018). Flexible work arrangements, national culture, organizational characteristics, and organizational outcomes: A study across 21 countries. Human Resource Management Journal, 2018; 28:182-200.

Peterson, J. \& Wiens-Tures, B. (2014). Work Time, Gender and Inequality: The Conundrums of Flexibility. Journal of Economic Issues. v. XLVIII, n, 2.

Richbell, S., Brookes, M., Brewster, C., \& Wood, G. (2011). Non-standard working time: an international and comparative analysis. The International Journal of Human Resource Management, 22(04), 945-962.

Schwartz, F.N. (1989). Management, Women and the New Facts of Life. Harvard Business Review, 89, p. 65-76.

Soares, J. \& Siqueira, A. (2002). Introdução à Estatística Médica. Belo Horizonte: Coopmed.

Sorj, B.; Fontes, A. \& Machado, D.C. (2007). Políticas e Práticas de Conciliação entre Família e Trabalho no Brasil. Cadernos de Pesquisa. v. 37, n. 132.

Vignoli, V.A. (2010). Flexibilização da Jornada de Trabalho: Importância e Limitações. Dissertação de Mestrado. São Paulo: Faculdade de Direito/USP.

Wilson, S., \& Hadler, M. (2017). Downward flexibility: Who is willing to take an inferior job? European Journal of Industrial Relations, 23(2), 187-204.

Zartaloudis, S., \& Kornelakis, A. (2017). Flexicurity between Europeanization and Varieties of Capitalism? A Comparative Analysis of Employment Protection Reforms in Portugal and Greece. JCMS: Journal of Common Market Studies, 55(5), 1144-1161.

\section{Appendix 1}

\section{Survey questions}

(Originally written in Portuguese, the native language of the interviewees ) 
Q1: Do you agree that the company you work for is adopting work flexibility policies and practices? (Flexibility policies and practices are actions that can reduce labor costs for the company and, on the other hand, provide flexibility for workers to, for example, choose their working schedule and work location according to their personal and family needs) - 5 point Likert Scale, totally agree ... totally disagree.

Q2: The company's flexibilization policies and practices are geared, in terms of gender, towards: men, women, both, there are no policies and practices in the company.

Q3: How does union participation occur in the negotiation of policies and practices to make working hours more flexible? The union does not participate; the union negotiates once a year but does not follow up; the union follows the day-to-day flexibilization practices in the company; besides following-up, the union has an internal workers' committee within the company.

Q4: Which other actors participate in the negotiation of policies and practices to make work flexible in the company? (You can select more than one option): the employee; the HR department; the immediate leadership; the legal department of the company; the union; all of them; none of them.

Q5: What are the policies and practices most adopted by your company in relation to the work flexibilization? (You can check more than one answer): part-time work; reduced work week; not go beyond the 8 hour workday; location flexibility through remote access technology; home office; flexible schedules; bank of hours; exchange of extra work hours for time off; limited leave of absence; unlimited leave of absence.

Q6: What are the main reasons why flexibilization policies and practices are not adopted in the company? (You can mark more than one answer): lack of interest from management; fear of violating labor laws; lack of knowledge about flexibilization practices; lack of union action; not believing that flexibilization creates value for the business.

Q7: What is the main positive return for the company and / or employees that justifies the adoption of labor flexibilization policies? Increased productivity; greater satisfaction with work; recruitment and retention of skilled workers; there is no positive return.

Q8: What is the main negative return for the company and / or employees in relation to the adoption of labor flexibilization policies? Less career development for employees who adopt flexible workdays; lower participation of employees who adopt flexibilization in training and development programs; a perception of low commitment of employees who adopt flexibilization; the marginalization of the work of employees who adopt flexibilization; there is no negative return for the company; there is no negative return for the employee. 